\title{
HUBUNGAN PENGHASILAN ORANG TUA DENGAN MOTIVASI MAHASISWA SARJANA KEPERAWATAN TINGKAT I, II, III, IV DALAM MELANJUTKAN STUDI PROFESI NERS DI STIKES ADVAITA MEDIKA TABANAN
}

\author{
Desak Gede Yenny Apriani ${ }^{1,1}$, Desak Made Firsia Sastra Putri ${ }^{1,2}$ \\ ${ }^{1}$ Prodi S1 Keperawatan Ners, ${ }^{2}$ STIKES Advaita Medika Tabanan \\ Korespondensi penulis: yennyapriani2004@gmail.com
}

\begin{abstract}
Abstrak
Latar belakang dan tujuan: Profesi keperawatan dituntut untuk memiiki kemampuan intelektual, interpersonal kemampuan teknis dan moral. Hal ini dapat ditempuh dengan meningkatkan kualitas perawat melalui pendidikan lanjutan pada program Pendidikan Ners. Penelitian ini bertujuan untuk mengetahui hubungan antara penghasilan orang tua dengan motivasi mahasiswa program sarjana keperawatan tingkat I,II,III,IV dalam dalam melanjutkan studi Profesi Ners.

Metode: Desain penelitian ini adalah observasi korelasional dengan pendekatan cross-sectional. Populasi pada penelitian ini adalah seluruh mahasiswa program sarjana keperawatan pada semua tingkat yaitu sebesar 80 responden dengan pemilihan sampel menggunakan teknik total sampling. Variabel terikat adalah motivasi mahasiswa dalam melanjutkan studi profesi ners sedangkan variabel bebas adalah penghasilan orang tua. Data dikumpulkan dengan metode angket menggunakan alat ukur kuesioner. Analisis dilakukan secara univariat untuk mendeskripsikan distribusi frekuensi dan secara bivariat menggunakan uji Person Chi-Square.

Hasil: Penelitian menunjukkan proporsi mahasiswa yang memiliki motivasi tinggi untuk melanjutkan studi profesi ners sebesar 35,0\%. Hasil analisis bivariat menunjukkan terdapat hubungan antara penghasilan orang tua dengan motivasi maahsiswa dalam melanjutkan studi profesi ners $(p<0,005)$. Pada responden yang memiliki orang tua berpenghasilan tinggi sebesar $59,4 \%$ memiliki motivasi yang tinggi untuk melanjutkan studi sedangkan pada responden yang memiliki orang tua berpenghasilan rendah hanya sebesar $18,8 \%$ yang memiliki motivasi tinggi untuk melanjutkan studi profesi ners.
\end{abstract}

Simpulan: terdapat hubungan penghasilan orang tua dengan motivasi mahasiswa sarjana keperawatan tingkat i, ii, iii, iv dalam melanjutkan studi profesi ners.

Kata kunci: penghasilan, motivasi, ners

\section{Pendahuluan}

Pelayanan keperawatan yang diberikan kepada masyarakat harus memenuhi standar mutu internasional, yang dapat menjamin keamanan dan kenyamanan klien beserta keluarganya. Perawat dituntut untuk tampil professional saat memberikan asuhan keperawatan serta mampu menjalin kerjasama dengan berbagai pihak agar pelayanan yang diberikan dilakukan secara komprehensif dan dapat memenuhi kebutuhan dasar, meliputi kebutuhan bio, psiko, sosio, dan spiritual klien. Sebagai profesi, keperawatan dituntut untuk memiiki kemampuan intelektual, interpersonal kemampuan teknis dan moral. Hal ini dapat ditempuh dengan meningkatkan kualitas perawat melalui pendidikan lanjutan pada program Pendidikan Ners. Dengan demikian, diharapkan terjadi perubahan yang mendasar dalam upaya berpartisipasi aktif untuk menyukseskan program pemerintah dan berwawasan yang luas tentang profesi keperawatan. (AIPNI, 2015) 
Kurikulum Inti Pendidikan Ners Indonesia 2015 terdiri atas kurikulum tahap akademik (Sarjana Keperawatan) dan kurikulum tahap profesi (Ners). Kurikulum ini disusun setelah mempertimbangkan bahwa Kurikulum Pendidikan Ners (tahap akademik Sarjana dan profesi Ners) yang disahkan pada tahun 2010 perlu dievaluasi dan disesuaikan dengan Kerangka Kualifikasi Nasional Indonesia (KKNI) yang tertuang dalam Peraturan Presiden Republik Indonesia Nomor 8 Tahun 2012 dan Peraturan Menteri Pendidikan dan 112 Kurikulum Inti Pendidikan Ners Indonesia 2015 Kebudayaan Republik Indonesia Nomor 73 Tahun 2013 tentang Penerapan Kerangka Kualifikasi Nasional Indonesia Bidang Pendidikan Tinggi menunjukkan matriks sebaran masing-masing stase dengan total sks yaitu 36 sks tersebar pada dua semester (AIPNI, 2015).

Jumlah perawat di Indonesia per 2 September 2019 sebanyak 532.040 orang (perawat yang telah teregistrasi di PPNI secara online/memiliki NIRA). Perlu ditekankan lagi data ini tidak termasuk perawat yang belum memiliki NIRA. Jawa Timur merupakan provinsi paling banyak perawat yang sudah memiliki NIRA PPNI yakni sebanyak 69.006 orang (SIMKA PPNI, 2019). Perbandingan data dari BPPSDMK Depkes (2015) jumlah perawat di Indonesia sebesar 223.910 orang sedangkan untuk tenaga medis 101.615. Jawa Tengah adalah provinsi dengan jumlah perawat terbanyak sebesar 29.154, sedangkan jumlah perawat paling sedikit adalah provinsi Gorontalo sebesar 1.086 (BPPSDMK, 2015).

Telah disepakati oleh semua institusi yang tergabung dalam Asosiasi Institusi Pendidikan Ners Indonesia bahwa lulusan profesi keperawatan yang siap bekerja atau telah memenuhi standar kompetensinya adalah lulusan Ners. AIPNI beranggotakan 324 perguruan tinggi di seluruh Indonesia yang rutin mengadakan rapat tahunan untuk membahas masalah yang terjadi dan rencana tindak lanjut terhadap pengelolaan instisusi terkait pelaksanaan Profesi Ners (Rahmawati Nur dan Widodo, 2011).

AIPNI sebagai sebuah asosisasi juga dikelola lebih khusus lagi di tingkat regional, wilayah Bali merupakan anggota di AIPNI Regional $X$ bergabung dengan NTB dan NTT. Bali memiliki 6 perguruan tinggi penyelenggara Ners, termasuk STIKES Advaita Medika Tabanan. Program studi profesi Ners di STIKES Advaita menerapkan kurikulum yang telah ditetapkan oleh AIPNI (Asosiasi Institusi Pendidkan Ners Indonesia) yaitu kurikulum berbasis KKNI. Masa studi profesi Ners dibagi menjadi 2 semester dengan total 36 SKS. Studi pendahuluan 2017 yaitu, motivasi mahasiswa dalam melanjutkan pendidikan tahap profesi Ners masih cenderung kurang. Data jumlah mahasiswa yang mengikuti pendidikan profesi Ners di Program Studi Ilmu Keperawatan STIKES Advaita Medika Tabanan menyebutkan bahwa mahasiswa angkatan 2015 yang melanjutkan pendidikan profesi Ners sebanyak $59 \%$ dan sekitar $41 \%$ yang tidak melanjutkan pendidikan profesi Ners. Sedangkan pada angkatan 2016 mahasiswa yang melanjutkan pendidikan profesi Ners sebanayak $70 \%$ dan sekitar 30\% yang tidak melanjutkan pendidikan ke jenjang profesi Ners.(STIKES Advaita Medika Tabanan 2017). Peneliti juga melakukan wawancara kepada 7 orang mahasiswa yang sudah pernah praktik lapangan diantaranya tingkat II, III, dan IV, bahwa 4 mahasiswa (57\%) mengatakan memilih jurusan $\mathrm{S} 1$ Keperawatan merupakan suruhan dari orang tua, mereka juga mengatakan motivasi belajar mereka kurang karena tugas menumpuk. Sementara itu 3 mahasiswa (43\%) lainnya mengatakan memilih S1 Keperawatan adalah minat yang diinginkan sendiri dan ingin menjadi perawat profesional.

Hasil wawancara pada 5 orang mahasiswa yang tidak melanjutkan profesi Ners, 3 diantaranya menyebutkan alasan biaya pendidikan yang cukup tinggi. Motivasi seseorang untuk melanjutkan 
pendidikan dipengaruhi oleh 2 faktor, yaitu internal dan eksternal. Kondisi sosial ekonomi, status ekonomi adalah sebuah komponen kelas sosial, mengacu pada tingkat pendapatan keluarga dan sumber pendapatan. Pendapatan yang mencukupi kebutuhan-kebutuhan keluarga termasuk salah satunya adalah perbaikan pendidikan. (Friedman, 1989). Berdasarkan hal tersebut maka peneliti tertarik untuk meneliti hubungan antara penghasilan orang tua dengan motivasi mahasiswa mahasiswa sarjana keperawatan tingkat i, ii, iii, iv dalam melanjutkan studi Profesi Ners STIKES Advaita Medika Tabanan.

\section{Metode Penelitian}

Rancangan penelitian ini adalah observasi korelasi dengan menggunakan pendekatan cross sectional. Penelitian ini dilaksanakan pada tanggal 7 dan 8 Mei 2019 dengan populasi sejumlah 80 orang mahasiswa S1 keperawatan ners tingkat 1,2, 3, dan 4 STIKES Advaita Medika Tabanan. Pengumpulan data tentang jenis kelamin, pekerjaan orang tua, penghasilan orang tua, tingkat kelas, dan motivasi mahasiswa dilakukan dengan pengisian kuesioner yang disebar dengan metode angket pada masingmasing responden. Sebelum pengumpulan data diberikan informed consent dan lembar persetujuan untuk berpartisipasi dalam penelitian yang ditandatangani oleh responden. Analisis dilakukan dengan univariat dan bivariat menggunakan aplikasi SPSS 21.0. Analisis univariat bertujuan untuk menggambarkan karakteristik subyek penelitian dan variabel penelitian lainnya. Analisis bivariat dilakukan untuk mengetahui hubungan antara kedua variabel.

\section{Hasil dan Pembahasan}

Pada tabel 1 disajikan frekuensi distribusi variabel berdasarkan jenis kelamin, pekerjaan orang tua, dan tingkat kelas responden. Tabel menunjukkan sebagian besar responden berjenis kelamin perempuan, pekerjaan orang tua sebagian besar sebagai wiraswasta dan distribusi paling banyak berasal dari tingkat II.

Pada tabel 2 disajikan proporsi responden yang memiliki motivasi untuk melanjutkan profesi Ners dan dijumpai bahwa responden yang memiliki motivasi tinggi sebesar 35,0\%. Pada tabel ini juga disajikan proporsi penghasilan orang tua dari responden dan dijumpai bahwa orang tua memiliki penghasilan tinggi sebesar 40,0\%.

Pada tabel 3 disajikan hasil analisis bivariat dengan uji Pearson Chi Square untuk mengetahui hubungan antara variabel bebas dan variabel terikat. Hasil uji menunjukkan terdapat hubungan yang signifikan antara penghasilan orang tua dengan motivasi yang dimiliki oleh responden dalam melanjutkan studi profesi Ners. 
Tabel 1. Karakteristik Responden

\begin{tabular}{|c|c|c|c|}
\hline No & Karakteristik & Jumlah (n) & Persentase $(\%)$ \\
\hline \multirow[t]{4}{*}{1} & Jenis Kelamin & & \\
\hline & Laki-laki & 12 & 15 \\
\hline & Perempuan & 68 & 85 \\
\hline & Total & 80 & 100 \\
\hline \multirow[t]{7}{*}{2} & Pekerjaan Orang Tua & & \\
\hline & PNS & 14 & 17,5 \\
\hline & Wiraswasta & 29 & 36,25 \\
\hline & Swata & 16 & 20 \\
\hline & Petani & 16 & 20 \\
\hline & Buruh & 5 & 6,25 \\
\hline & Total & 80 & 100 \\
\hline \multirow[t]{6}{*}{3} & Tingkat Kelas & & \\
\hline & $\mathrm{I}$ & 16 & 20 \\
\hline & II & 26 & 32,5 \\
\hline & III & 18 & 22,5 \\
\hline & IV & 20 & 25 \\
\hline & Total & 80 & 100 \\
\hline
\end{tabular}

Tabel 2. Variabel Penelitian

\begin{tabular}{cllcc}
\hline No & \multicolumn{1}{c}{ Karakteristik } & Jumlah (n) & Persentase (\%) \\
\hline \multirow{2}{*}{1} & Penghasilan Orang Tua & & \\
\cline { 2 - 4 } & Tinggi & 32 & 40 \\
\cline { 2 - 4 } & Rendah & 48 & 60 \\
\cline { 2 - 4 } & Total & 80 & 100 \\
\hline 2 & Motivasi & 14 & 17,5 \\
\cline { 2 - 4 } & Tinggi & 29 & 36,25 \\
\cline { 2 - 4 } & Rendah & 80 & 100 \\
\cline { 2 - 4 } & Total &
\end{tabular}

Tabel 3. Hubungan Pengasilan Orang Tua dengan Motivasi Mahasiswa

\begin{tabular}{cccccccc}
\hline \multirow{2}{*}{$\begin{array}{c}\text { Penghasilan } \\
\text { Orang Tua }\end{array}$} & \multicolumn{2}{c}{ Motivasi Mahasiswa } & \multicolumn{2}{c}{ Total } & \multirow{2}{*}{ p-Value } \\
\cline { 2 - 6 } & \multicolumn{2}{c}{ Tinggi } & \multicolumn{2}{c}{ Rendah } & & & \\
\cline { 2 - 7 } & $\mathrm{f}$ & $\%$ & $\mathrm{f}$ & $\%$ & $\mathrm{f}$ & $\%$ & \multirow{2}{*}{0,000} \\
\hline Tinggi & 19 & 59,4 & 13 & 40,6 & 32 & 100 & \\
\hline Rendah & 9 & 18,8 & 39 & 81,3 & 48 & 100 & \\
\hline
\end{tabular}

Pada penelitian ini dijumpai sebesar $40,0 \%$ responden yang memiliki orang tua berpenghasilan tinggi dan sebesar 60,0\% responden memiliki orang tua berpenghasilan rendah. Berdasarkan hasil penelitian pula didapatkan dari 80 responden, sebagian besar orang tua bekerja sebagai wiraswasta. Wiraswasta adalah jenis pekerjaan yang beragam dan dapat mengerjakan bermacam-macam pekerjaan. Wiraswasta juga berarti keberanian, keutamaan serta keperkasaan dalam memenuhi kebutuhan serta memecahkan permasalahan hidup dengan kekuatan yang ada pada diri sendiri (Wasty Soemanto, 1984 dalam Alma 2010). Berdasarkan hasil pengamatan yang termasuk dalam wiraswasta pada penelitian ini adalah orang tua yang bekerja sebagai pedagang kecil dan memiliki industri rumah tangga. Usaha tersebut tidak menjanjikan hasil yang tetap setiap bulannnya.

Hasil penelitian menunjukkan proporsi yang memiliki motivasi tinggi untuk melanjutkan profesi Ners sebesar 35,0\% dan sisanya memiliki motivasi yang rendah. Menurut Notoatmodjo (2012), motivasi merupakan dorongan dari dalam diri 
seseorang menyebabkan orang tersebut melakukan kegiatan-kegiatan tertentu untuk mencapai suatu tujuan. Motivasi yang tinggi yang dimiliki oleh mahasiswa terhadap program ners disebabkan mahasiswa memahami bahwa program ners merupakan salah satu prasyaratan yang dibutuhkan oleh mahasiswa ketika nanti akan memasuki dunia kerja. Kondisi ini disebabkan pada saat ini, sebagian besar institusi kesehatan mensyaratkan profesionalisme kepada perawatnya, sehingga mahasiswa harus mengikuti program ners untuk memperoleh gelar profesionalimesnya sebagai perawat. Program ners juga merupakan syarat untuk melanjutkan kejenjang pendidikan keperawatan yang lebih tinggi. Motivasi yang rendah dimiliki oleh mahasiswa terhadap program ners disebabkan mahasiswa masih merasa ragu untuk melanjutkan ners, salah satunya diungkapkan adalah alasan biaya pendidikan yang cukup tinggi.

Diantara responden yang memiliki orang tua berpenghasilan tinggi sebesar $59,4 \%$ yang memiliki motivasi tinggi untuk melanjutkan studi profesi Ners. Sedangkan diantara responden yang memiliki orang tua berpenghasilan rendah, hanya sebesar $18.8 \%$ yang memiliki motivasi tinggi untuk melanjutkan studi profesi Ners. Hamalik (2010) menyatakan bahwa status sosial ekonomi di lingkungan keluarga merupakan salah satu faktor eksternal timbulnya motivasi melanjutkan pendidikan anak ke jenjang yang lebih tinggi. Hasil penelitian ini juga sesuai dengan penelitian yang dilakukan oleh Rahmawati dan Widodo pengaruh orangtua dalam memberikan masukan saran atau nasehat dan dorongan motivasi untuk melanjutkan pendidikan profesi ners menunjukkan yang berkategori baik dengan persentase terbesar sebanyak 47 orang $(54,7 \%)$. Sedangkan pengaruh orangtua yang berkategori kurang baik dengan persentase paling sedikit sebanyak 39 orang $(45,3 \%)$. Penghasilan orang tua juga ikut menentukan dalam mempengaruhi penentuan sikap responden untuk melanjutkan studi ners. Hal ini juga diungkapkan oleh Aryanto (2015) bahwa minat melanjutkan studi ke perguruan tinggi disebabkan oleh pertimbangan yang bersifat sosial ekonomi dan mempunyai hubungan yang sistematis dan signifikan dengan variabel seperti umur, jenis kelamin, tahun terakhir di SMK, jumlah anak dan teman-teman di luar sekolah.

Berdasarkan hasil pengamatan, mahasiswa yang memiliki motivasi rendah untuk melanjutkan studi ke jenjang profesi ners memiliki beberapa alasan. Alasan pertama dan terbanyak yang disampaikan ialah biaya pendidikan yang dirasa cukup tinggi. Mereka mengatakan orang tua belum sanggup untuk membiayai pendidikan profesi ners. Penghasilan orang tua yang tergolong sedang dan rendah menjadikan mahasiswa untuk tidak melanjutkan pendidikan, ada rasa ketakutan apabila dipaksakan akan terhenti di tengah perjalanan studi. Hasil ini sejalan dengan penelitian yang dilakukan oleh Bempechat dan Shernoff (2012) yang menyatakan bahwa tingkat social ekonomi orang tua berpengaruh pada putusnya sekolah. Peneliti sempat mewancarai orang tua mahasiswa yang datang ke kampus dan menyatakan ketidaksanggupan untuk membiayai anaknya melanjutkan studi. Ada pula yang mengatakan karena ada saudara kandung yang juga sedang menempuh pendidikan sehingga mereka merasa cukup untuk lulus sarjana keperawatan saja. Selain itu disebutkan pula penghasilan sebagai wiraswasta yang tidak tetap setiap bulannya menjadikan dalam melakukan pembayaran biaya kuliah sering terlambat bahkan sampai tidak bisa membayar. Sistem pembayaran yang berlaku di STIKES Advaita Medika adalah ada pilihan pembayaran dengan angsuran setiap bulannya. Adanya keringanan tersebut ternyata juga masih menjadi ketakutan bagi mahasiswa maupun orang tua dalam melanjutkan pendidikan.

\section{Simpulan}

Terdapat hubungan antara penghasilan orang tua dengan motivasi mahasiswa program sarjana keperawatan tingkat i, ii, iii, iv dalam melanjutkan studi profesi Ners di STIKES Advaita Medika Tabanan. 


\section{Referensi}

AIPNI. 2015. Kurikulum Inti

Pendidikan Ners Indonesia. Jakarta; Asosiasi Institusi Pendidikan Ners Indonesia (AIPNI).

Alma, B. 2010. Kewirausahaan.Edisi Revisi. Bandung: Alfabeta Bandung.

Aryanto, E A. 2015. Pengaruh Motivasi Belajar dan Tingkat Pendapatan Orang Tua terhadap Minat Melanjutkan Studi ke Perguruan Tinggi Siswa Kelas XI SMAN 1 Jogonalan Tahun Ajaran 2015/2016 [skripsi].

Badan Pengembangan dan Pemberdayaan Sumber Daya Manusia Kesehatan (BPPSDMK) Kementerian Kesehatan Republik Indonesia. 2015 http://bppsdmk.depkes.go.id/ Diakses tanggal 19 Oktober 2019.

Bempechat, J \& Shernoff, D.J. 2012. Parental Influences on Achievement Motivation and Student Engagement. https://doi.org/10.1007/978-1-46142018-7_15

Friedman David.1989. Law and Economic: What and Why. Journal of the Institute of Economic Affairs. https://doi.org/10.1111/j.14680270.1989.tb01119.x.

Hamalik. 2010. Proses Belajar Mengajar. Jakarta: Bumi Aksara

Notoatmodjo, S. 2012. Imu Perilaku Kesehatan. Jakarta: Rineka Cipta.

Rahmawati N \& Widodo A.2019. FaktorFaktor yang Mempengaruhi Motivasi Mahasiswa Sarjana Keperawatan untuk Melanjutkan Pendidikan Profesi Ners di Universitas Muhammadiyah Surakarta. Surakarta: Universitas Muhammadiyah Surakarta.

SIMK online PPNI. http://simk.innappni.or.id/login/ Diakses tanggal 17 Oktober 2019 